\title{
Distal Bile Duct Cancer pT2 TNM Finding v7
}

National Cancer Institute

\section{Source}

National Cancer Institute. Distal Bile Duct Cancer PT 2 TNM Finding V7. NCI Thesaurus.

Code C90250.

Distal bile duct cancer with tumor invading beyond the wall of the bile duct. (from AJCC 7th Ed.) 